DOI: $10.15193 / \mathrm{ZNTJ} / 2018 / 115 / 236$

\author{
HANNA MOJSKA, IWONA GIELECIŃSKA
}

\title{
TRENDY ZMIAN ZAWARTOŚCI AKRYLOAMIDU W PRODUKTACH ZIEMNIACZANYCH W POLSCE W LATACH 2004 - 2016
}

\begin{abstract}
Streszczenie
Celem pracy była analiza i ocena trendów zmian zawartości akryloamidu w czipsach i frytkach gotowych do spożycia, przebadanych w ramach ogólnopolskich badań monitoringowych w latach 2004 - 2016. Ocenę istotności różnic między zawartościami akryloamidu w poszczególnych kategoriach produktów ziemniaczanych przeprowadzono z zastosowaniem nieparametrycznego testu średnich rang KruskalaWallisa, przyjmując istotność różnic na poziomie $\mathrm{p}<0,05$.

Największą przeciętną statycznie istotną $(\mathrm{p}<0,05)$ zawartość akryloamidu stwierdzono w czipsach ziemniaczanych $(398 \mu \mathrm{g} / \mathrm{kg})$, a w następnej kolejności we frytkach pobranych z barów i restauracji $(292 \mu \mathrm{g} / \mathrm{kg})$ oraz we frytkach przygotowanych w laboratorium $\mathrm{z}$ handlowych półproduktów mrożonych $(200 \mu \mathrm{g} / \mathrm{kg})$. We wszystkich trzech przebadanych kategoriach produktów ziemniaczanych stwierdzono tendencję malejącą zawartości akryloamidu, przy czym istotną $(\mathrm{p}<0,001)$ różnicę pomiędzy początkowym i końcowym okresem badań stwierdzono w przypadku czipsów i frytek smażonych z półproduktów. Nie obserwowano istotnego trendu zmniejszania/zwiększania zawartości akryloamidu w produktach ziemniaczanych na przestrzeni 13 badanych lat. Istotny $(\mathrm{p}<0,0001)$ trend zmniejszania zawartości akryloamidu był stwierdzony wyłącznie w latach 2007 - 2012 i tylko w grupie frytek smażonych z handlowych półproduktów mrożonych.

W celu zmniejszenia zawartości akryloamidu w żywności powinny być podejmowane skuteczniejsze działania, zarówno ze strony producentów produktów ziemniaczanych, jak i legislatorów. Biorąc pod uwagę niekorzystne działanie akryloamidu na zdrowie człowieka, obniżenie jego poziomu w żywności powinno być priorytetem w zarządzaniu ryzykiem.
\end{abstract}

Słowa kluczowe: akryloamid, produkty ziemniaczane, czipsy, frytki smażone, trendy zmian

\section{Wprowadzenie}

Akryloamid powstaje w żywności w wyniku reakcji Maillarda pomiędzy wolną asparaginą a cukrami redukującymi, głównie glukozą i fruktozą, pod wpływem tempe-

Dr hab. n. farm. H. Mojska, prof. nadzw., mgr inż. I. Gielecińska, Zakład Metabolomiki, Instytut Żywności i Żywienia, ul. Powsińska 61/63,02-903 Warszawa. Kontakt: hmojska@izz.waw.pl 
ratury powyżej $120^{\circ} \mathrm{C}[21,29]$. Głównym źródłem akryloamidu w diecie są produkty ziemniaczane, m.in. frytki i czipsy, przetwory zbożowe, w tym pieczywo, płatki śniadaniowe i różnego rodzaju ciasteczka oraz kawa i jej substytuty $[5,15,19,22,28]$.

W licznych badaniach wykazano, że akryloamid jest związkiem neurotoksycznym i może przyczyniać się do uszkodzenia centralnego i obwodowego układu nerwowego, zarówno u zwierząt doświadczalnych, jak i u ludzi narażonych na ten związek w miejscu pracy $[3,10,25]$. W badaniach prowadzonych na zwierzętach obserwowano wzrost przypadków wystąpienia guzów nowotworowych wielu organów, m.in. sutka, macicy, nadnerczy i tarczycy po podawaniu akryloamidu w wodzie do picia $[2,9,14]$.

Wyniki uzyskiwane w badaniach z udziałem ludzi są niejednoznaczne. W kilku badaniach $[11,12,16,23]$ wykazano związek pomiędzy wzrostem poziomu biomarkerów ustrojowych akryloamidu u ludzi, będącego efektem pobrania tego związku z dietą, a wzrostem ryzyka rozwoju raka. Wyniki innych badań $[4,24]$ nie potwierdziły związku pomiędzy pobraniem akryloamidu z dietą a ryzykiem rozwoju nowotworów różnych organów.

Międzynarodowa Agencja Badań nad Rakiem [13] już w 1994 r. zaliczyła akryloamid do związków „prawdopodobnie rakotwórczych dla ludzi” (grupa 2A) uznając, że chociaż dowody na rakotwórcze działanie akryloamidu na organizm człowieka są ograniczone, to dowody takiego działania w badaniach na zwierzętach doświadczalnych są dobrze udokumentowane.

Oszacowane w ostatnich latach narażenie na akryloamid pochodzący z żywności, które w Europie waha się w zakresie $0,4 \div 1,9 \mu \mathrm{g} / \mathrm{kg}$ m.c./dzień oraz obliczone na tej podstawie marginesy narażenia (ang. Margin of Exposure, MOE) wynoszące poniżej 10000 [6] wskazują jednoznacznie, że akryloamid stanowi problem zdrowia publicznego i należy podjąć działania zmierzające do obniżenia pobierania tego związku $\mathrm{z}$ dietą.

W celu oceny poziomu akryloamidu w jak największej liczbie produktów obecnych na rynku europejskim od 2007 r. prowadzony jest ogólnoeuropejski monitoring zawartości akryloamidu w żywności [30, 31]. Wyniki badań monitoringowych z poszczególnych krajów przesyłane są do Europejskiego Urzędu ds. Bezpieczeństwa Żywności (EFSA), gdzie są gromadzone i poddawane ocenie, a następnie publikowane w postaci raportów i opinii [6 - 8]. Na podstawie raportu EFSA [8] w 2013 r. Komisja Europejska wydała zalecenie Nr 2013/647/UE w sprawie dochodzeń dotyczących poziomów akryloamidu w żywności [32], w którym określono wartości wskaźnikowe dla tego związku w odniesieniu do 20 grup produktów spożywczych. Należy podkreślić, że wartości wskaźnikowe nie stanowią najwyższych dopuszczalnych poziomów (NDS) akryloamidu w żywności, a ich przekroczenie nie skutkuje wycofaniem produktów z rynku. Obecnie obowiązuje nowe Rozporządzenie Komisji (UE) 2017/2158 z dnia 20 listopada 2017 r. ustanawiające środki łagodzące i poziomy odniesienia służące ogra- 
niczeniu obecności akryloamidu w żywności [27], które wprowadza bardziej restrykcyjne wartości ww. poziomów odniesienia (wartości wskaźnikowych) w stosunku do większości grup środków spożywczych. Należy podkreślić, że również producenci żywności podejmują dobrowolne działania zmierzające do zmniejszania zawartości omawianego związku w środkach spożywczych. Od 2005 r. Organizacja Europejskich Producentów Napojów i Żywności (CIAA, obecnie Food Drink Europe) publikuje kolejne wersje ,narzędzi” do obniżania poziomu akryloamidu w żywności, tzw. toolbox [1]. „Narzędzia”, nazywane obecnie ,środkami łagodzącymi”, wskazują na praktyczne możliwości działań na etapie m.in. doboru surowców, receptury, warunków procesu technologicznego na rzecz obniżenia poziomu akryloamidu w produkcie finalnym. Pomimo podejmowanych działań ocenia się jednak, na podstawie dotychczasowych wyników badań monitoringowych, że zawartość akryloamidu w żywności nadal jest duża i waha się w bardzo szerokim zakresie od poniżej $10 \mu \mathrm{g} / \mathrm{kg}$ (pieczywo świeże) do nawet $7000 \mu \mathrm{g} / \mathrm{kg}$ (substytuty kawy).

Celem pracy była analiza i ocena trendów zmian zawartości akryloamidu w wybranych kategoriach produktów ziemniaczanych w Polsce na przestrzeni ostatnich kilkunastu lat.

\section{Material i metody badań}

Ocenę trendów zmian zawartości akryloamidu w produktach ziemniaczanych w latach 2004 - 2016 przeprowadzono z wykorzystaniem bazy danych Zakładu Metabolomiki Instytutu Żywności i Żywienia (IŻŻ). Baza zawiera wyniki oznaczeń zawartości akryloamidu w żywności, w tym w 368 próbkach produktów ziemniaczanych przebadanych w ramach ogólnopolskich badań monitoringowych ${ }^{1}$. W latach 2004 2016 badaniami objęto trzy rodzaje produktów ziemniaczanych poddanych obróbce termicznej: czipsy ziemniaczane, frytki gotowe do spożycia pobrane z zakładów gastronomicznych oraz frytki przygotowane w laboratorium $\mathrm{z}$ handlowych półproduktów mrożonych, zgodnie z instrukcją producenta podaną na opakowaniu. Rodzaje i liczbę przebadanych w poszczególnych latach próbek produktów ziemniaczanych przedstawiono w tab. 1.

Próbki były pobierane przez pracowników Państwowej Inspekcji Sanitarnej na terenie całego kraju w losowo wybranych sklepach lub zakładach gastronomicznych (bary, restauracje) na terenie każdego województwa, zgodnie z autorskimi wytycznymi i harmonogramem opracowanymi w Instytucie Żywności i Żywienia. Od roku 2007 podstawę wytycznych stanowiły kolejne zalecenia Komisji Europejskiej [30, 31]. Czipsy i frytki były pobierane dwukrotnie w ciągu każdego roku w marcu i listopadzie ze względu na możliwość wpływu warunków przechowywania ziemniaków na poziom

\footnotetext{
${ }^{1}$ Badania monitoringowe w latach 2004 - 2016 były prowadzone we współpracy z Głównym Inspektoratem Sanitarnym.
} 
cukrów redukujących, a w efekcie na zawartość akryloamidu w produkcie finalnym. Jedną próbkę stanowiły co najmniej dwa opakowania handlowe produktu z tej samej partii produkcyjnej lub dwie porcje produktu z zakładów gastronomicznych w ilości nie mniejszej niż 200 - $300 \mathrm{~g}$ w zależności od rodzaju produktu (lata 2004 - 2006) oraz nie mniejszej niż $1 \mathrm{~kg}$ (lata 2007 - 2016).

Zawartość akryloamidu w ww. próbkach produktów ziemniaczanych pobranych w latach 2004 - 2009 oznaczano w Laboratorium Referencyjnym Instytutu Żywności i Żywienia metodą chromatografii gazowej sprzężonej z tandemową spektrometrią mas (GCQ-MS/MS) [19] (lata 2004 - 2007) oraz metodą chromatografii cieczowej sprzężonej z tandemową spektrometrią mas (LC-MS/MS) [18] (lata 2008 - 2009). Metodą GCQ-MS/MS oznaczono akryloamid z wykorzystaniem chromatografu gazowego sprzężonego ze spektrometrem mas firmy Finnigan Matt (USA). W przypadku metody LC-MS/MS zastosowano chromatograf cieczowy UltiMate 3000 firmy Dionex (Niemcy) sprzężony ze spektrometrem mas 3200 QTrap firmy ABSciex (Kanada). W latach 2011 - 2016 zawartość akryloamidu w pobieranych próbkach produktów ziemniaczanych była oznaczana $w$ laboratoriach dwóch wojewódzkich stacji sanitarnoepidemiologicznych metodą chromatografii gazowej sprzężonej ze spektrometrią mas (GC-MS), a wyniki oznaczeń przekazywano do IŻŻ. Metody wykorzystane do oznaczenia zawartości akryloamidu w żywności są metodami poddanymi walidacji, spełniającymi kryteria określone w zaleceniu Komisji UE w sprawie monitorowania poziomów akryloamidu w żywności [30, 31]. Laboratoria uczestniczące w badaniach monitoringowych posiadają w zakresie ww. metod akredytację Polskiego Centrum Akredytacji.

Do statystycznej analizy wyników zawartości akryloamidu w produktach ziemniaczanych wykorzystano pakiet statystyczny Statistica ver. 6.0 (Statsoft, Inc.). Ocenę istotności różnic pomiędzy wartościami przeciętnymi (medianami) akryloamidu w grupach produktów ziemniaczanych oraz w obrębie grup pomiędzy początkowym a końcowym okresem badań wykonano testem U Manna-Whitneya.

Analizę trendów zmian zawartości akryloamidu w poszczególnych kategoriach produktów ziemniaczanych przeprowadzono z zastosowaniem nieparametrycznego testu średnich rang Kruskala-Wallisa. We wszystkich zastosowanych testach statystycznych przyjęto poziom istotności różnic przy p $<0,05$.

\section{Wyniki i dyskusja}

Udział procentowy poszczególnych kategorii w ogólnej liczbie przebadanych próbek produktów ziemniaczanych przedstawiono na rys. 1 . 


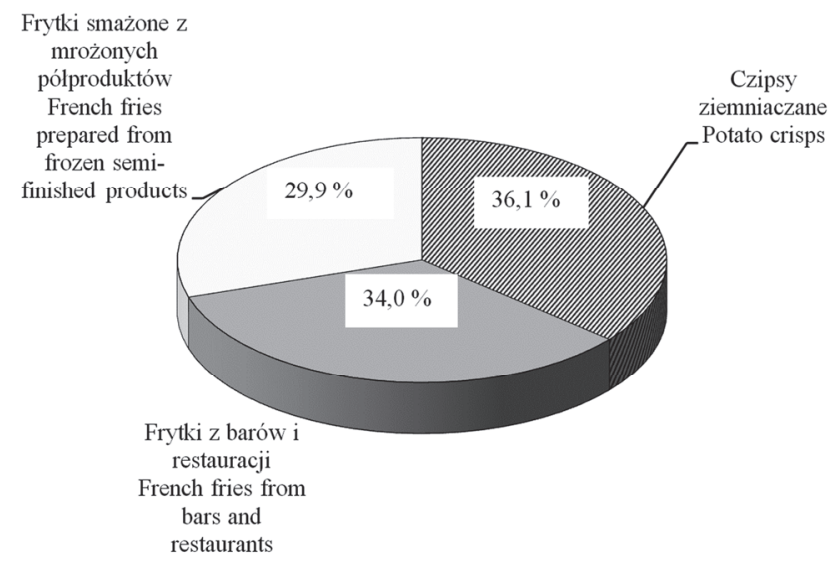

Rys. 1. Udział procentowy liczby próbek z poszczególnych grup produktów ziemniaczanych przebadanych w latach 2004 - 2016

Fig. 1. Percent number of samples from individual groups of potato products tested in $2004-2016$

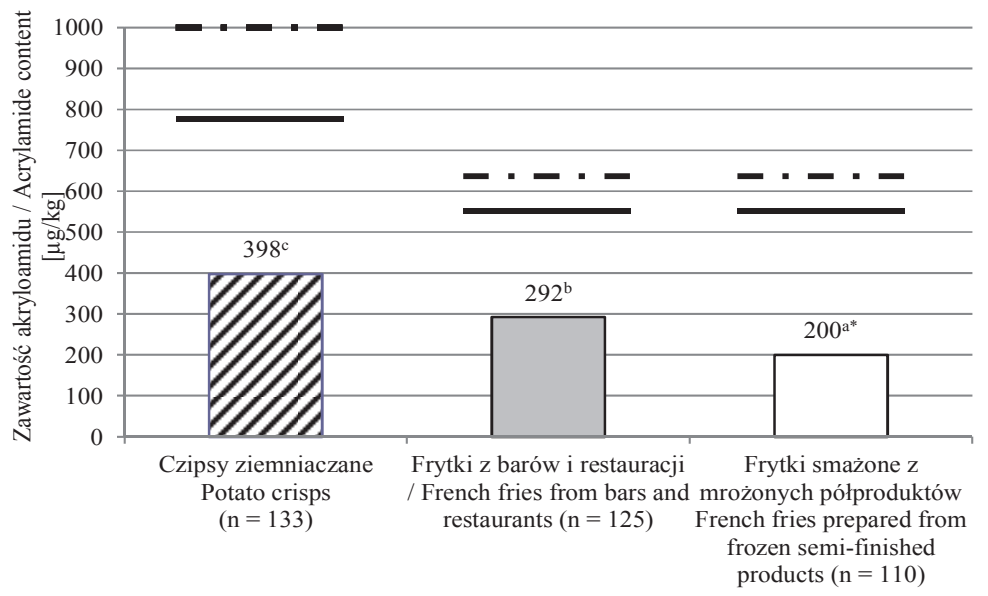

Objaśnienia / Explanatory notes:

- wartości wskaźnikowe wg zalecenia nr 2013/647/UE / check value according to the recommendation no. 2013/647/EU [32]

- • - - aktualne poziomy odniesienia wg rozporządzenia nr 2017/2158 [27] / current benchmarks levels according to the regulation no. 2017/2158 [27]

* - różnica statystycznie istotna $(\mathrm{p}<0,05)$ pomiędzy przeciętną zawartością (medianą) akryloamidu oznaczoną w poszczególnych grupach produktów / statistically significant difference $(\mathrm{p}<0.05)$ between mean acrylamide content (median) as determined in individual products groups. Wartości oznaczone różnymi literami różnią się statystycznie istotnie. / Values denoted by different letters differ statistically significantly.

Rys. 2. Porównanie przeciętnej zawartości (mediana) akryloamidu w wybranych grupach produktów ziemniaczanych przebadanych w Polsce w latach 2004 - 2016

Fig. 2. Comparison of mean content (median) of acrylamide in selected groups of potato products tested in Poland in $2004-2016$ 
Przeciętną zawartość (medianę) akryloamidu w wybranych 3 grupach produktów ziemniaczanych przebadanych w ramach ogólnopolskich badań monitoringowych na przestrzeni lat $2004-2016$ przedstawiono na rys. 2.

Największą, statystycznie istotną $(\mathrm{p}<0,05)$, przeciętną zawartość akryloamidu stwierdzono w czipsach ziemniaczanych $(398 \mu \mathrm{g} / \mathrm{kg})$, a w następnej kolejności we frytkach pobranych z barów i restauracji $(292 \mu \mathrm{g} / \mathrm{kg})$ oraz we frytkach przygotowanych w laboratorium z mrożonych półproduktów $(200 \mu \mathrm{g} / \mathrm{kg})$. We wszystkich kategoriach produktów ziemniaczanych przebadanych w latach 2004 - 2016, przeciętna zawartość akryloamidu nie przekraczała wartości wskaźnikowych określonych w zaleceniu Komisji Nr 2013/647/UE [32]. Warto podkreślić, że oznaczona zawartość akryloamidu nie przekraczała również aktualnie obowiązujących poziomów odniesienia [27]. Uzyskane wyniki były zbliżone do przeciętnej zawartości akryloamidu w czipsach ziemniaczanych $(389 \mu \mathrm{g} / \mathrm{kg})$ oraz we frytkach smażonych $(196 \mu \mathrm{g} / \mathrm{kg})$ w Europie, obliczonej na podstawie ogólnoeuropejskich badań monitoringowych prowadzonych w latach 2007 - 2012 [6]. Porównywalne z wynikami własnymi były rezultaty badań prowadzonych w latach 2002 - 2013 w Belgii [5]. W belgijskich czipsach ziemniaczanych zawartość akryloamidu wynosiła przeciętnie $408 \mu \mathrm{g} / \mathrm{kg}$, a we frytkach gotowych do spożycia - $180 \mu \mathrm{g} / \mathrm{kg}$. Z kolei w badaniach, które przeprowadzili Normandin i wsp. [22] w Kanadzie oraz Mesias i Morales [17] w Hiszpanii, zawartość akryloamidu w czipsach ziemniaczanych wynosiła przeciętnie ok. $560 \mu \mathrm{g} / \mathrm{kg}$. Jeszcze większą średnią zawartość akryloamidu w czipsach, na poziomie $954 \mu \mathrm{g} / \mathrm{kg}$, stwierdzili Sirot i wsp. [28] we Francji. W przypadku frytek smażonych wyniki uzyskiwane w badaniach kanadyjskich [22] i francuskich [28] były ponad 2,5 raza wyższe w porównaniu z przeciętną zawartością stwierdzoną w Polsce. Należy przy tym zaznaczyć, że w cytowanych pracach $[17,22,28]$ oceniano zawartość akryloamidu w próbkach produktów pobieranych jednorazowo w określonym czasie i najczęściej w jednym mieście lub regionie.

Rozkłady liczby próbek w zależności od poziomu akryloamidu w poszczególnych kategoriach produktów ziemniaczanych przedstawiono na rys. 3 - 5. W 81 próbkach czipsów ziemniaczanych, co stanowiło ponad $60 \%$ próbek, zawartość akryloamidu mieściła się w zakresie $82 \div 500 \mu \mathrm{g} / \mathrm{kg}$, a w ok. $90 \%$ - nie przekraczała obowiązującej w tych latach [32] wartości wskaźnikowej $(1000 \mu \mathrm{g} / \mathrm{kg})$ (rys. 3). Analiza próbek frytek pobranych $\mathrm{z}$ barów i restauracji oraz frytek smażonych z mrożonych półproduktów wykazała, że w ponad $70 \%$ próbek zawartość akryloamidu nie przekraczała $400 \mu \mathrm{g} / \mathrm{kg}$ (rys. 4 i rys. 5). Warto jednak zwrócić uwagę, że podobnie jak w przypadku czipsów ok. $10 \%$ próbek przekraczało wartości wskaźnikowe $(600 \mu \mathrm{g} / \mathrm{kg})$ z roku $2013(5,6 \%$ próbek frytek pobranych z barów i restauracji oraz 11,8 \% próbek frytek smażonych z półproduktów) [32]. W odniesieniu do aktualnych wymagań (750 i $500 \mu \mathrm{g} / \mathrm{kg}$ ) [27] jest to odpowiednio: $21,8 \%$ próbek czipsów, 16,8 \% frytek pobranych z barów i re- 
stauracji oraz $17,3 \%$ frytek smażonych z półproduktów. Należy przy tym podkreślić, że największe zawartości akryloamidu w pojedynczych próbkach produktów, znacząco przekraczające wartości wskaźnikowe, stwierdzane były w pierwszych latach prowadzenia badań monitoringowych (tab. 1). Uzyskane wyniki wydają się wskazywać na skuteczność podejmowania przez producentów tzw. działań łagodzących na etapie pozyskiwania surowców, receptur i procesu technologicznego, zmierzających do obniżania poziomu akryloamidu w produktach finalnych.

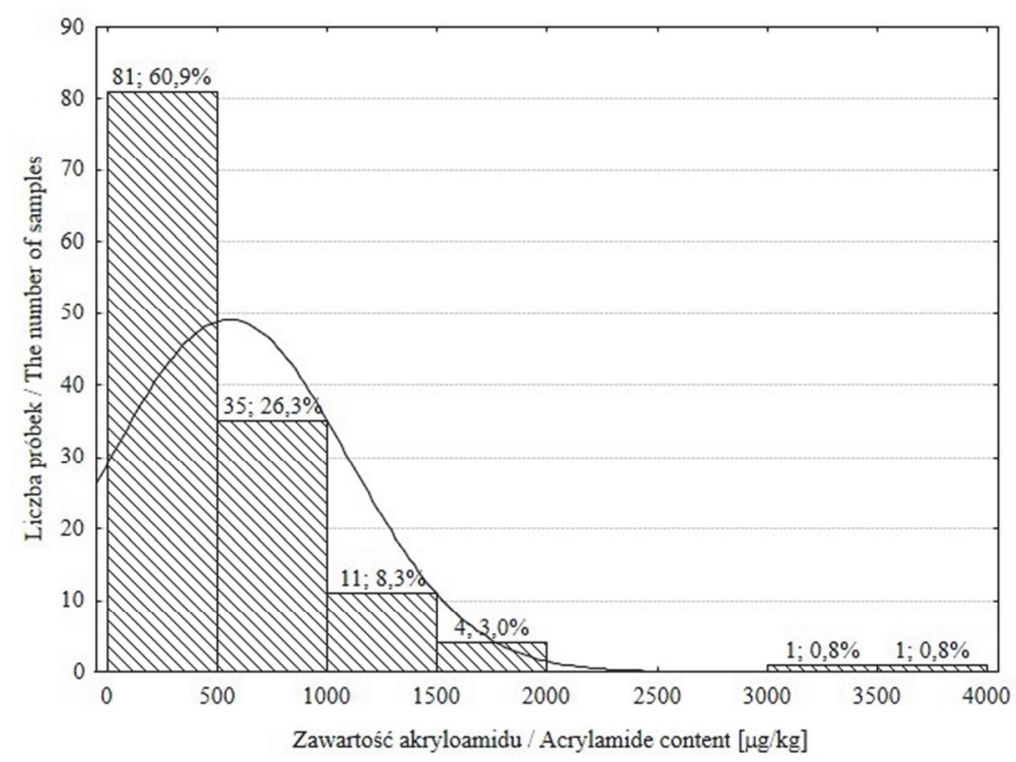

Rys. 3. Rozkład liczby próbek czipsów ziemniaczanych w zależności od zawartości akryloamidu (n = 133)

Fig. 3. Distribution of number of potato crisps samples depending on acrylamide level $(n=133)$

Na podstawie analizy statystycznej uzyskanych danych wykazano tendencję malejącą zawartości akryloamidu we wszystkich trzech badanych kategoriach produktów ziemniaczanych. Największe (ponad 4-krotne) zmniejszenie przeciętnej zawartości badanego związku stwierdzono we frytkach smażonych z półproduktów (tab. 1), natomiast $\mathrm{w}$ czipsach ziemniaczanych zawartość ta $\mathrm{w}$ badanym okresie zmniejszyła się ponad dwukrotnie: z 753 do $375 \mu \mathrm{g} / \mathrm{kg}$. W obydwu tych grupach różnice pod względem zawartości akryloamidu pomiędzy początkowym a końcowym okresem badań były statystycznie istotne $(\mathrm{p}<0,001)$. W przypadku frytek pobranych $\mathrm{z}$ barów i restauracji obniżenie poziomu akryloamidu na przestrzeni 13 lat wynosiło ok. $20 \%$, jednak różnica pomiędzy wynikami w początkowym a końcowym okresem badania nie była statystycznie znamienna. 


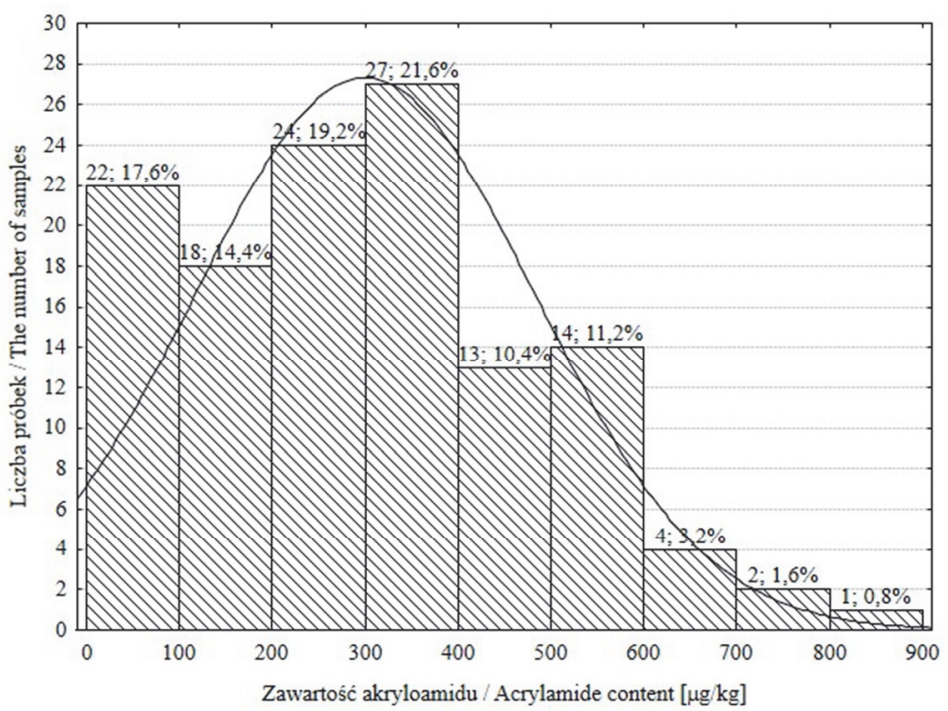

Rys. 4. Rozkład liczby próbek frytek smażonych pobranych z barów i restauracji w zależności od zawartości akryloamidu $(\mathrm{n}=125)$

Fig. 4. Distribution of number of French fries samples collected from bars and restaurant depending on acrylamide level $(\mathrm{n}=125)$

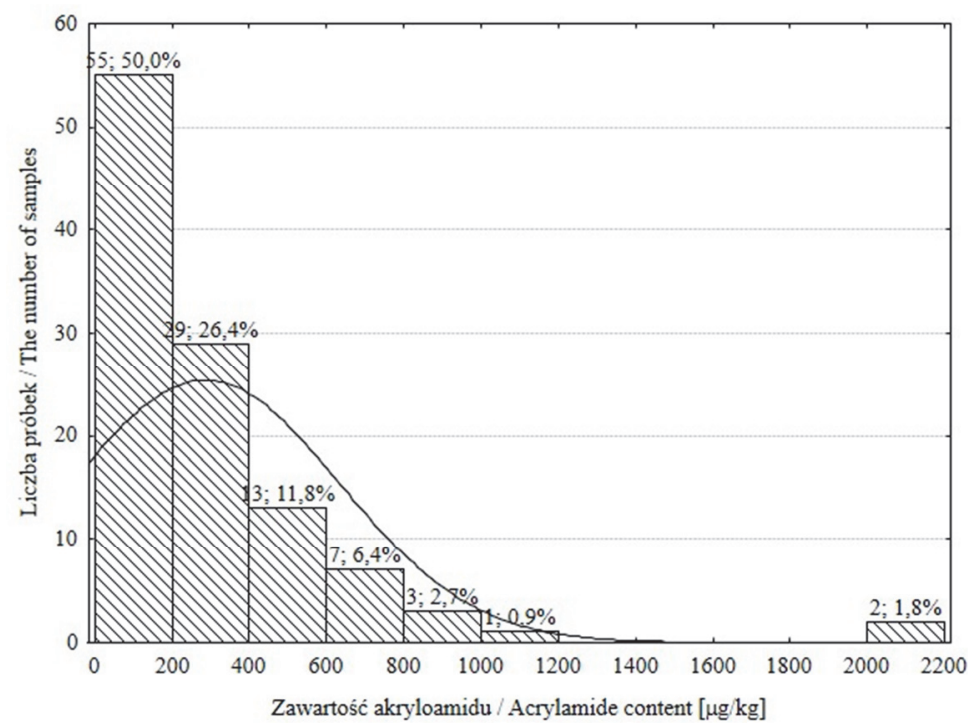

Rys. 5. Rozkład liczby próbek frytek smażonych z mrożonych półproduktów w zależności od zawartości akryloamidu $(\mathrm{n}=110)$

Fig. 5. Distribution of number of French fries samples from semi-finished products depending on acrylamide level $(\mathrm{n}=110)$ 
Tabela 1. Porównanie zawartości akryloamidu w czipsach i frytkach ziemniaczanych przebadanych w Polsce latach 2004 - 2016

Table 1. Comparison of acrylamide level in potato crisps and French fries tested in Poland in the years $2004-2016$

\begin{tabular}{|c|c|c|c|}
\hline \multirow{2}{*}{$\begin{array}{l}\text { Rok badania } \\
\text { Year }\end{array}$} & \multirow{2}{*}{$\begin{array}{l}\text { Liczba próbek } \\
\text { Number of samples }\end{array}$} & \multicolumn{2}{|c|}{$\begin{array}{c}\text { Zawartość akryloamidu } \\
\text { Acrylamide level }[\mu \mathrm{g} / \mathrm{kg}]\end{array}$} \\
\hline & & $\mathrm{Me}$ & Zakres / Range \\
\hline \multicolumn{4}{|c|}{ Czipsy ziemniaczane / Potato crisps } \\
\hline 2004 & 24 & $753^{\mathrm{b}}$ & $352 \div 3647$ \\
\hline 2007 & 7 & 484 & $113 \div 1673$ \\
\hline 2008 & 14 & 654 & $320 \div 1890$ \\
\hline 2009 & 14 & 538 & $190 \div 1974$ \\
\hline 2011 & 13 & 160 & $92 \div 1418$ \\
\hline 2012 & 13 & 246 & $106 \div 585$ \\
\hline 2013 & 10 & 389 & $82 \div 992$ \\
\hline 2014 & 12 & 193 & $105 \div 985$ \\
\hline 2015 & 13 & 180 & $109 \div 672$ \\
\hline 2016 & 13 & $375^{\mathrm{a}^{*}}$ & $122 \div 964$ \\
\hline \multicolumn{4}{|c|}{$\begin{array}{l}\text { Frytki pobrane } \mathrm{z} \text { barów i restauracji } \\
\text { French fries collected from bars and restaurants }\end{array}$} \\
\hline 2005 & 9 & 307 & $155 \div 799$ \\
\hline 2007 & 7 & 333 & $134 \div 518$ \\
\hline 2008 & 14 & 419 & $235 \div 679$ \\
\hline 2009 & 14 & 379 & $130 \div 735$ \\
\hline 2011 & 14 & 120 & $12,5 \div 813$ \\
\hline 2012 & 17 & 344 & $12,5 \div 628$ \\
\hline 2013 & 10 & 257 & $93 \div 527$ \\
\hline 2014 & 14 & 110 & $16 \div 534$ \\
\hline 2015 & 13 & 219 & $34 \div 479$ \\
\hline 2016 & 13 & 246 & $41 \div 462$ \\
\hline \multicolumn{4}{|c|}{$\begin{array}{l}\text { Frytki smażone } \mathrm{z} \text { mrożonych półproduktów } \\
\text { French fries from frozen semi-finished products }\end{array}$} \\
\hline 2007 & 7 & $796^{b}$ & $347 \div 2175$ \\
\hline 2008 & 14 & 506 & $263 \div 866$ \\
\hline 2009 & 14 & 258 & $157 \div 729$ \\
\hline 2011 & 14 & 106 & $12 \div 286$ \\
\hline 2012 & 11 & 64 & $3,7 \div 345$ \\
\hline 2013 & 10 & 258 & $99 \div 816$ \\
\hline 2014 & 10 & 60 & $9,3 \div 286$ \\
\hline 2015 & 16 & 78 & $17 \div 457$ \\
\hline 2016 & 14 & $176^{\mathrm{a}^{*}}$ & $12,5 \div 580$ \\
\hline
\end{tabular}

Objaśnienia / Explanatory notes:

$\mathrm{Me}$ - mediana / median;

* - różnica statystycznie istotna $(\mathrm{p}<0,001)$ pomiędzy przeciętną zawartością (medianą) akryloamidu oznaczoną w tej samej grupie produktów pomiędzy początkowym a końcowym okresem badań / statistically significant difference $(\mathrm{p}<0.001)$ between mean acrylamide content (median) determined in the same group of products in the initial and final testing period. Wartości średnie oznaczone różnymi literami różnią się statystycznie istotnie. / Mean values denoted by different letters differ statistically significantly. 
Ocenę trendów zmian zawartości akryloamidu na przestrzeni lat $2004-2016$ przedstawiono na rys. $6-8$.

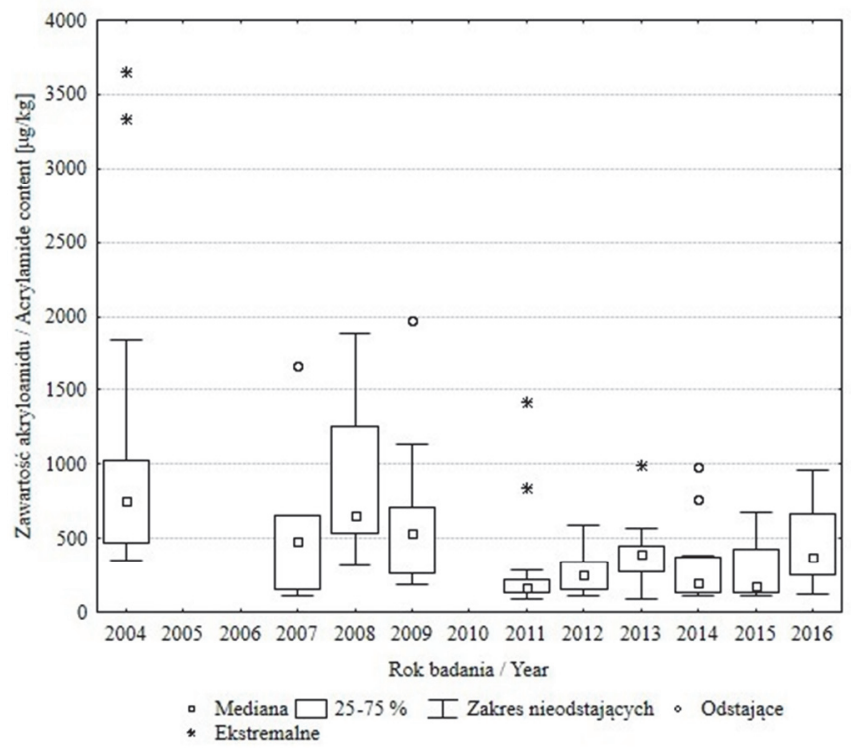

Rys. 6. Rozkład zawartości akryloamidu w czipsach ziemniaczanych, pobranych z rynku w latach 2004 - 2016

Fig. 6. Distribution of acrylamide content in potato crisps, collected from the market in years 2004 2016

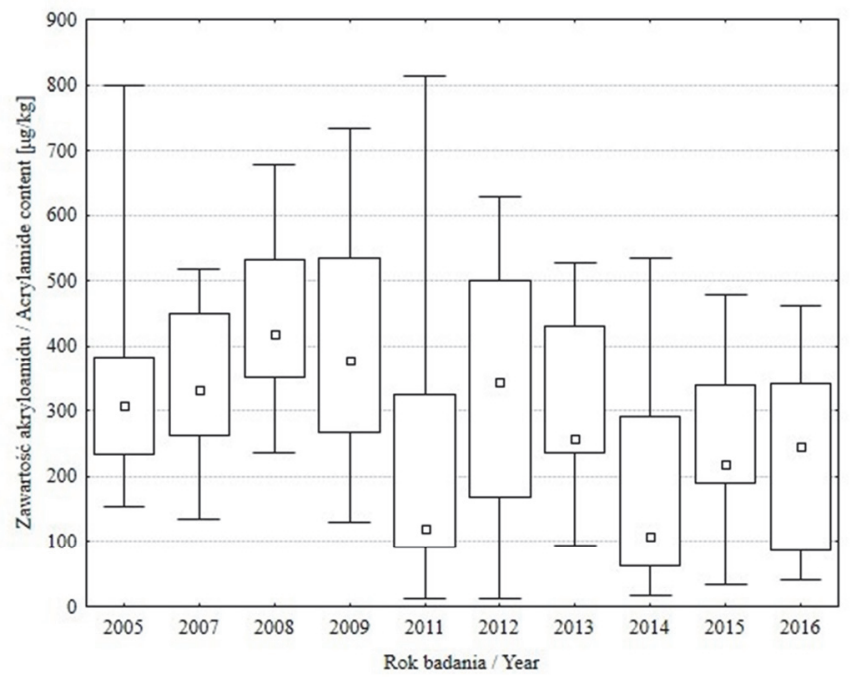

口 Mediana $\square 25.75 \%$ 工 Min-Maks

Rys. 7. Rozkład zawartości akryloamidu we frytkach pobranych z barów i restauracji w latach 2005 2016

Fig. 7. Distribution of acrylamide content in French fries, collected from bars and restaurants in years $2005-2016$ 


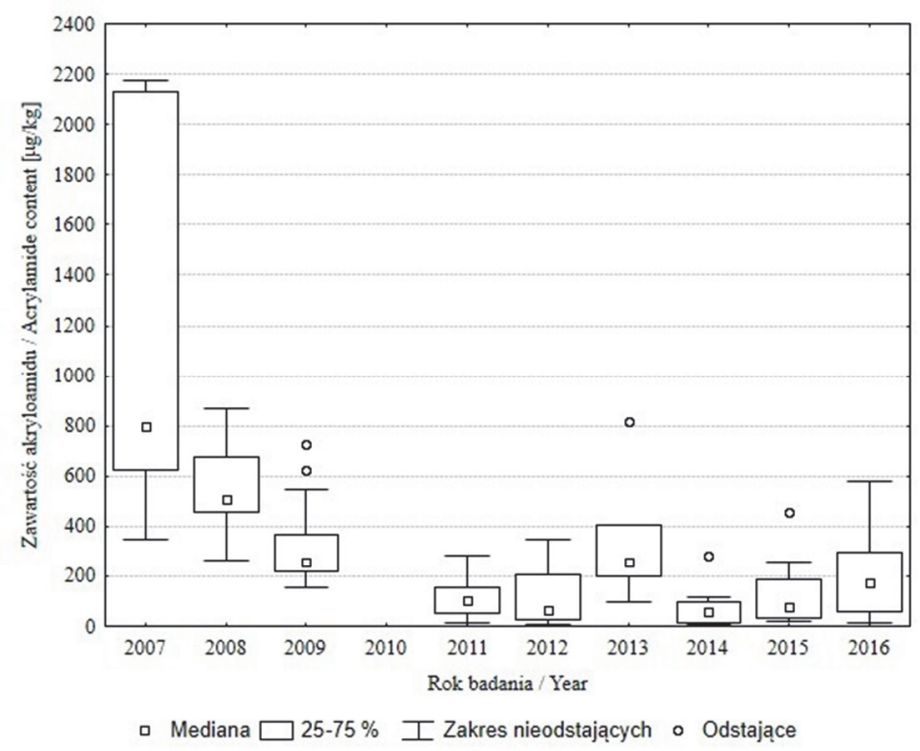

Rys. 8. Rozkład zawartości akryloamidu we frytkach smażonych z mrożonych półproduktów, pobranych z rynku w latach 2007 - 2016

Fig. 8. Distribution of acrylamide content in French fries from frozen semi-finished products collected from the market in years 2007 - 2016

$\mathrm{Na}$ podstawie analizy statystycznej danych wykazano brak istotnego trendu zmniejszania/zwiększania zawartości akryloamidu w produktach ziemniaczanych. Warto jednak zaznaczyć, że istotny $(\mathrm{p}<0,0001)$ trend zmniejszania zawartości akryloamidu obserwowano $\mathrm{w}$ przypadku frytek smażonych $\mathrm{z}$ mrożonych półproduktów w latach 2007 - 2012 [20]. W okresie tym obserwowano największe zmniejszenie przeciętnej zawartości badanego związku: z 796 do $64 \mu \mathrm{g} / \mathrm{kg}$. W $2013 \mathrm{r}$. w tej grupie produktów obserwowano 4-krotny jednoroczny wzrost, a następnie obniżenie do poziomu z 2012 r. Od roku 2014 obserwowany jest ponowny wzrost zawartości akryloamidu, który nie przekroczył jednak wartości z roku 2009. W przypadku frytek pobranych z zakładów gastronomicznych początkowo (2005 - 2008) obserwowano wzrost poziomu akryloamidu do wartości $419 \mu \mathrm{g} / \mathrm{kg}$ (maksymalna przeciętna zawartość na przestrzeni 13 lat), a następnie serię obniżeń i wzrostów poziomu akryloamidu. Stwierdzony w latach 2007 - 2012 istotny trend obniżania poziomu akryloamidu we frytkach smażonych z mrożonych półproduktów wydaje się wskazywać na skuteczne stosowanie mechanizmów zmniejszania zawartości akryloamidu przez producentów sektora ziemniaczanego, m.in. w zakresie wyboru właściwych odmian surowca i warunków jego przechowywania, warunków obróbki wstępnej oraz warunków wstępnego smażenia półproduktów. Z drugiej strony zastanawiający jest brak trendu obniżania 
poziomu badanego związku we frytkach gotowych do spożycia pobranych z zakładów gastronomicznych. Może to świadczyć o nie w pełni wdrożonych środkach łagodzących m.in. w zakresie kontroli półproduktów i na etapie smażenia frytek w barach i restauracjach.

Z kolei w grupie czipsów ziemniaczanych od 2004 r. obserwowane jest powolne zmniejszanie zawartości badanego związku, jednak, podobnie jak w przypadku frytek pobranych z barów i restauracji, obserwuje się nieznaczne krótkookresowe wahania wzrostowo-malejące w tym okresie badań. Nie stwierdzono jednak istotnego trendu zmniejszania zawartości akryloamidu na przestrzeni 13 badanych lat w chipsach ziemniaczanych. Wyniki uzyskane w niniejszej pracy nie potwierdzają wykazanego przez Powersa $\mathrm{i}$ wsp. [26] istotnego $(\mathrm{p}<0,001)$ trendu obniżenia poziomu akryloamidu w czipsach ziemniaczanych na podstawie danych pochodzących od producentów czipsów w Europie w latach 2002 - 2011. Podobnie do wyników badań własnych, przeprowadzona przez EFSA analiza ogólnoeuropejskich trendów zmian zawartości akryloamidu w różnych kategoriach żywności, w tym w produktach ziemniaczanych, wskazuje, że istotny ogólnoeuropejski trend obniżania poziomu badanego związku był stwierdzony wyłącznie $\mathrm{w}$ grupie produktów dla niemowląt i małych dzieci $[6,20]$. Może to wskazywać na nieskuteczność działań podejmowanych przez producentów na różnych etapach produkcji, mających na celu zmniejszenie zawartości akryloamidu w produkcie finalnym. Jednocześnie EFSA podkreśla, że badany okres czterech lat może być zbyt krótki do oceny istotności zachodzących zmian.

Podsumowując, należy podkreślić, że w Polsce rozpoczęto prowadzenie zaplanowanych badań monitoringowych zawartości akryloamidu w żywności już w 2004 r., a więc trzy lata przed wejściem w życie zalecenia Komisji UE w sprawie monitorowania zawartości tego związku w żywności w Europie [30]. W odniesieniu do trendów zmian zawartości akryloamidu w Polsce należy zwrócić uwagę na długoletni okres obserwacji (13 lat), który pozwala na wyeliminowanie wpływu krótkoterminowych zmian poziomów badanego związku. Istotna jest również regularność czasowa i stałość miejsc poboru próbek do badań oraz stała podobna liczba wykonanych badań w każdym roku (tab. 1). Na podstawie uzyskanych wyników nie wykazano istotnych trendów zmian zawartości akryloamidu w żadnej z trzech badanych grup produktów ziemniaczanych, jednak $\mathrm{w}$ każdej $\mathrm{z}$ tych kategorii stwierdzano znaczne zmniejszenie zawartości pomiędzy początkowym a końcowym okresem badań. Wyniki wydają się potwierdzać stosowanie przez producentów produktów ziemniaczanych środków łagodzących w celu obniżania poziomu akryloamidu w produkcie gotowym do spożycia. Działania te powinny być jednak skuteczniejsze, tak, aby uzyskać efektywne zmniejszenia zawartości akryloamidu w produktach ziemniaczanych. Biorąc pod uwagę niekorzystne działanie akryloamidu na organizm człowieka, obniżenie jego poziomu powinno być priorytetem w zarządzaniu ryzykiem. 


\section{Wnioski}

1. Na podstawie wyników badań monitoringowych zawartości akryloamidu w produktach ziemniaczanych w Polsce w latach 2004 - 2016 stwierdzono statystycznie istotne $(\mathrm{p}<0,001)$ obniżenie poziomu badanego związku w chipsach oraz frytkach smażonych z półproduktów pomiędzy początkowym a końcowym okresem badań.

2. W ocenie zmian zawartości akryloamidu w produktach ziemniaczanych w badanym okresie nie wykazano jednak istotnych trendów obniżania poziomu akryloamidu w badanych kategoriach produktów.

3. Ze względu na niekorzystne działanie akryloamidu na organizm człowieka zarówno zarządzający ryzykiem, jak i producenci żywności powinni podejmować skuteczniejsze działania w celu zmniejszenia zawartości akryloamidu w produktach spożywczych.

\section{Literatura}

[1] FoodDrinkEurope: Acrylamide Toolbox 2013. [on line]. Dostęp w Internecie [6.06.2018]: http://www.fooddrinkeurope.eu/uploads/publications_documents/AcrylamideToolbox_2013.pdf

[2] Beland F.A., Mellick P.W., Olson G.R., Mendoza M.C.B., Marques M.M., Doerge D.R.: Carcinogenicity of acrylamide in $\mathrm{B}_{6} \mathrm{C}_{3} \mathrm{~F}_{1}$ mice and $\mathrm{F} 344 / \mathrm{N}$ rats from a 2-year drinking water exposure. Food Chem. Toxicol., 2013, 51, 149-159.

[3] Bergmark E.: Hemoglobin adducts of acrylamide and acrylonitrile in laboratory workers, smokers and nonsmokers. Chem. Res. Toxicol., 1997, 10, 78-84.

[4] Burley V.J., Greenwood D.C., Hepworth S.J., Fraser L.K., de Kok T.M., van Breda S.G., Kyrtopoulos S.A., Botsivali M., Kleinjans J., McKinney P.A., Cade J.E.: Dietary acrylamide intake and risk of breast cancer in the UK women's cohort. Br. J. Cancer, 2010, 103, 1749-1754.

[5] Claeys W., De Meulenaer B., Huyghebaert A., Scippo M.-L., Hoet P., Matthys C.: Reassessment of the acrylamide risk: Belgium as a case-study. Food Control, 2016, 59, 628-635.

[6] European Food Safety Authority: Scientific opinion on acrylamide in food. [on line]. EFSA Journal 2015, 13 (6), \#4104. Dostęp w Internecie [6.06.2018]: https://www.efsa.europa.eu/en/ efsajournal/pub/4104

[7] European Food Safety Authority: Results on acrylamide levels in food from monitoring years 20072009 and exposure assessment. [on line]. EFSA Journal 2011, 9 (4), \#2133. Dostęp w Internecie [6.06.2018]: http://www.efsa.europa.eu/en/efsajournal/pub/2133

[8] European Food Safety Authority: Update on acrylamide levels in food from monitoring years 2007 to 2010. [on line]. EFSA Journal 2012, 10 (10), \#2938. Dostęp w Internecie [6.06.2018]: https://www.efsa.europa.eu/en/efsajournal/pub/2938

[9] Friedman M.A., Dulak L.H., Stedham M.A.: A lifetime oncogenicity study in rats with acrylamide. Fundam. Appl. Toxicol., 1995, 27, 95-105.

[10] He F.S., Zhang S.L., Wang H.L., Li G., Zhang Z.M., Li F.L., Dong X.M., Hu F.: Neurological and electroneuromyographic assessment of the adverse effects of acrylamide on occupationally exposed workers. Scand. J. Work Environ. Health, 1989, 15, 125-129.

[11] Hogervorst J.G., Schouten L.J., Konings E.J., Goldbohm R.A., van den Brandt P.A.: A prospective study of dietary acrylamide intake and the risk of endometrial ovarian and breast cancer. Cancer Epidemiol. Biomarkers Prev., 2007, 16, 2304-2313. 
[12] Hogervorst J.G., Schouten L.J., Konings E.J., Goldbohm R.A., van den Brandt P.A.: Dietary acrylamide intake and risk of renal cell, bladder, and prostate cancer. Am. J. Clin. Nutr., 2008, 87, 1428-1438.

[13] International Agency for Research on Cancer (IARC): IARC monographs on the evaluation of carcinogenic risks to humans. Vol. 60. Acrylamide. IARC, Lyon 1994, pp. 389-433.

[14] Johnson K., Gorzinski S., Bodnar K., Campbell R., Wolf C., Friedman M., Mast R.: Chronic toxicity and oncogenicity study on acrylamide incorporated in the drinking water of Fisher 344 rats. Toxicol. Appl. Pharmacol., 1986, 85, 154-168.

[15] Konings E.J.M., Baars A.J., van Klaveren J.D., Spanjer M.C., Rensen P.M., Hiemstra M., van Kooij J.A., Peters P.W.J.: Acrylamide exposure from foods of the Dutch population and an assessment of the consequent risk. Food Chem. Toxicol., 2003, 41, 1569-1579.

[16] Lin Y., Lagergren J., Lu Y.: Dietary acrylamide intake and risk of esophageal cancer in a population-based case-control study in Sweden. Int. J. Cancer, 2011, 128, 676-681.

[17] Mesías M., Morales F.J.: Acrylamide in commercial potato crisps from Spanish market: Trends from 2004 to 2014 and assessment of the dietary exposure. Food Chem. Toxicol., 2015, 81, 104-110.

[18] Mojska H., Gielecińska I., Stoś K.: Determination of acrylamide level in commercial baby foods and an assessment of infant dietary exposure. Food Chem. Toxicol., 2012, 50, 2722-2728.

[19] Mojska H., Gielecińska I., Szponar L., Ołtarzewski M.: Estimation of the dietary acrylamide exposure of the Polish population. Food Chem. Toxicol., 2010, 48, 2090-2096.

[20] Mojska H.: Secular trends in food acrylamide. W: Acrylamide in food. Analysis, content and potential health effects. Ed. V. Gökmen. Academic Press, San Diego 2016, pp. 39-59.

[21] Mottram D.S., Wedzicha B.L., Dodson A.T.: Food chemistry: Acrylamide is formed in the Maillard reaction. Nature, 2002, 419, 448-449.

[22] Normandin L., Bouchard M., Ayotte P., Blanchet C., Becalski A., Bonvalot Y., Phaneuf D., Lapointe C., Gagné M., Courteau M.: Dietary exposure to acrylamide in adolescents from a Canadian urban center. Food Chem. Toxicol., 2013, 57, 75-83.

[23] Olesen P.T., Olsen A., Frandsen H., Frederiksen K., Overvad K., Tjonneland A.: Acrylamide exposure and incidence of breast cancer among postmenopausal women in the Danish diet, cancer and health study. Int. J. Cancer, 2008, 122, 2094-2100.

[24] Pelucchi C., La Vecchia C., Bosetti C., Boyle P., Boffetta P.: Exposure to acrylamide and human cancer - a review and meta-analysis of epidemiologic studies. Ann. Oncol., 2011, 22, 1487-1499.

[25] Pennisi M., Malaguarnera G., Puglisi V., Vinciguerra L., Vacante M., Malaguarnera M.: Neurotoxicity of acrylamide in exposed workers. Int. J. Environ. Res. Public Health, 2013, 10, 3843-3854.

[26] Powers S.J., Mottram D.S., Curtis A., Halford N.G.: Acrylamide concentrations in potato crisps in Europe from 2002 to 2011. Food Addit. Contam. Part A, 2013, 30 (9), 1493-1500.

[27] Rozporządzenie Komisji (UE) nr 2017/2158 z dnia 20 listopada 2017 r. ustanawiające środki łagodzące i poziomy odniesienia służące ograniczeniu obecności akryloamidu w żywności. Dz. U. UE L 304, ss. 24-44, z 21.11.2017.

[28] Sirot V., Hommet F., Tard A., Leblanc J.-C.: Dietary acrylamide exposure of the French population: Results of the second French total diet study. Food Chem. Toxicol., 2012, 50, 889-894.

[29] Stadler R.H., Scholz G.: Acrylamide: An update on current knowledge in analysis, levels in food, mechanisms of formation, and potential strategies of control. Nutr. Rev., 2004, 62, 449-467.

[30] Zalecenie Komisji nr 2007/331/WE z dnia 3 maja 2007 r. w sprawie monitorowania poziomów akrylamidu w żywności. Dz. U. UE L 123, ss. 33-40, z 12.05.2007.

[31] Zalecenie Komisji nr 2010/307/WE z dnia 2 czerwca 2010 r. w sprawie monitorowania poziomów akryloamidu w żywności. Dz. U. UE L 137, ss. 4-10, z 03.06.2010.

[32] Zalecenie Komisji nr 2013/647/UE z dnia 8 listopada 2013 r. w sprawie dochodzeń dotyczących poziomów akryloamidu w żywności. Dz. U. UE L 301, ss. 15-17, z 12.11.2013. 


\title{
CHANGE TRENDS IN ACRYLAMIDE LEVEL IN POTATO PRODUCTS IN POLAND IN 2004 - 2016
}

\author{
$\mathrm{S} u \mathrm{~mm}$ a r y
}

The objective of the research study was to analyse and evaluate the trends as regards changes in acrylamide level in ready-to-eat potato crisps and French fries tested under the national monitoring studies in the years 2004 to 2016. The significance of differences between the contents of acrylamide in the individual food categories was evaluated using a Kruskal-Wallis $\mathrm{H}$ test by ranks with the significance of differences assumed to be $\mathrm{p}<0.05$.

The highest statistically significant $(p<0.05)$ median of the content of acrylamide was found in the potato crisps $(398 \mu \mathrm{g} / \mathrm{kg})$ followed by the French fries from bars and restaurants $(292 \mu \mathrm{g} / \mathrm{kg})$ as well as in the French fries $(200 \mu \mathrm{g} / \mathrm{kg})$ prepared from the frozen semi-finished products in a laboratory. In the three categories of potato products analyzed, it was found that the acrylamide content level tended to decrease whereas a significant $(p<0.001)$ difference between the initial and the final testing period was reported in the potato crisps and French fries prepared from the semi-finished products.

No significant tendency was reported as regards the decreasing/increasing content of acrylamide in potato products over a period of 13 years of analyses. A significant $(p<0.0001)$ trend was found only in the group of French fries prepared from the frozen semi-finished products: the content of the acrylamide tended to decrease in those products exclusively in a period between 2007 and 2012.

In order to decrease the content of acrylamide in food, more effective actions should be taken by both the producers of potato products and the legislators. Considering the adverse effect of acrylamide on human health, the lowering of the acrylamide level should be regarded as priority in food risk management.

Key words: : acrylamide, potato products, potato crisps, French fries, change trends 